\section{Size-Fractionation of RNA by Hot Agarose Electrophoresis}

BioTechniques 28:414-416 (March 2000)

Since RNA molecules commonly form stable secondary structures, agarose gel size-fractionation of RNA is routinely achieved by chemical denaturing conditions during electrophoresis. This implies the use of toxic compounds such as methylmercuric hydroxide (1), formaldehyde (3) or cumbersome electrophoretic conditions using glyoxal and dimethylsulfoxide (4) after RNA denaturation. Here, we describe an alternative method in which the RNA molecules are preserved in a denatured state simply by maintaining a high temperature $\left(\mathrm{ca} .50^{\circ} \mathrm{C}\right.$ ) during the electrophoretic separation. To prove the feasibility of the proposed system, we have focused our analysis on ribosomal RNA (rRNA) molecules because it is well known that they form strong, stable secondary structures. We have compared the relative electrophoretic mobility of rRNAs from three distantly related organisms (rat, fruit fly and bacteria) using three different systems: standard non-denaturing agarose gel electrophoresis (5) in $1 \times$ TAE buffer (40 mM Tris-acetate, $\mathrm{pH}$ 8.0, $1 \mathrm{mM}$ EDTA), formaldehyde agarose gel electrophoresis (2) in HEPES buffer (20 mM HEPES, pH 7.4, 1 mM EDTA, $\mathrm{pH}$ 8.0, 0.45 $\mathrm{M}$ formaldehyde) and the hot-gel system described below. Moreover, we also demonstrated that RNA size-fractionated under hot conditions is perfectly suitable for blotting and hybridization analysis with a nonradioactive DNA probe, and it gives higher sensitivity in the Northern blot than other optimized procedures that use formaldehyde gels.

Total RNA was extracted employing TRI REAGENT ${ }^{\mathrm{TM}}$ (Sigma, St. Louis, MO, USA) following the manufacturer's instructions. For both hot and formaldehyde gel electrophoresis, 10 $\mu \mathrm{L}$ of total RNA preparations were mixed with $10 \mu \mathrm{L}$ of formaldehyde buffer (40 mM HEPES, pH 7.4, 2 mM EDTA, $\mathrm{pH}$ 8.0, $4 \mathrm{M}$ formaldehyde, $60 \%$ formamide), denatured by heating

Table 1. rRNA Sizes Estimated Using Formaldehyde and Hot Electrophoresis in Comparison with the Exact Data from GenBank. Length Values are Given in kb

\begin{tabular}{|ccccc|}
\hline Organism & rRNA & $\begin{array}{c}\text { Sequence Data } \\
\text { (GenBank) }\end{array}$ & $\begin{array}{c}\text { Formaldehyde } \\
\text { Electrophoresis Electrophoresis }\end{array}$ & $\begin{array}{c}\text { Hot } \\
\text { Rattus }\end{array}$ \\
norvegicus & $28 \mathrm{~S}$ & 4.780 & 4.6 & 5.0 \\
Drosophila & $28 \mathrm{~S} \alpha$ & 1.874 & 1.6 & 1.9 \\
melanogaster & $28 \mathrm{~S} \beta$ & 1.787 & 1.8 & 1.8 \\
& $18 \mathrm{~S}$ & 1.995 & 2.1 & 2.0 \\
Escherichia & $23 \mathrm{~S}$ & 2.904 & 1.9 & 1.9 \\
coli & $16 \mathrm{~S}$ & 1.542 & 2.6 & 2.8 \\
\end{tabular}

at $75^{\circ} \mathrm{C}$ for $5 \mathrm{~min}$ and chilled immediately on ice/ethanol. Then, $2 \mu \mathrm{L}$ of gel loading buffer $(50 \%$ glycerol, $1 \mathrm{mM}$ EDTA pH $8.0,0.25 \%$ bromophenol blue, $0.25 \%$ xylene cyanol) were added to the samples. For non-denaturing agarose gel electrophoresis, $1 \mu \mathrm{L}$ of loading buffer was added to $10 \mu \mathrm{L}$ of RNA samples. In all cases, the electrophoresis was run in $1.2 \%$ agarose gels using the GNA 100 horizontal gel apparatus (Amersham Pharmacia Biotech, Uppsala, Sweden). Separations were ended when the bromophenol dye marker reached the bottom of the gel slab (45 min for the hot agarose and $2 \mathrm{~h}$ for the formaldehyde gel). To achieve the hot conditions during electrophoresis, the $1 \times$ TAE buffer was heated to $60^{\circ} \mathrm{C}$, poured into the apparatus in which the gel had already been placed and, when the temperature reached $50^{\circ} \mathrm{C}$, a $15 \mathrm{~min}$ pre-electrophoresis at $10 \mathrm{~V} / \mathrm{cm}(130-140 \mathrm{~mA})$ was conducted. Subsequently, denatured RNA samples were loaded and the gel was run at $5 \mathrm{~V} / \mathrm{cm}$. Under these conditions, the buffer temperature remained constant at $50^{\circ} \mathrm{C} \pm 2^{\circ} \mathrm{C}$. Gels were stained in 0.5 $\mu \mathrm{g} / \mathrm{mL}$ ethidium bromide in diethylpyrocarbonate (DEPC)-treated water for $15 \mathrm{~min}$ and visualized under UV light. In the case of the formaldehyde gel, satisfactory visualization of bands required two subsequent $30 \mathrm{~min}$ destaining washes in DEPC-treated water.

For Northern analysis, we carried out nonradioactive detection of rat glyceraldehyde-3-phosphate dehydrogenase RNA. A 400 bp DNA fragment was labelled with DIG-dUTP using the random primed labeling kit (Roche Molec- ular Biochemicals, Mannheim, Germany). In the case of the formaldehyde gel, downward transfer was carried out according to the improved method of Ingelbrecht et al. (2). In the case of hot agarose gel electrophoresis, the transfer was accomplished by standard downward capillary using 10× standard saline citrate (SSC) as transfer buffer (20× $\mathrm{SSC}$ is $3 \mathrm{M} \mathrm{NaCl}, 0.3 \mathrm{M}$ sodium citrate, $\mathrm{pH}$ 7.0). In both cases, the transfers were stopped after $2.5 \mathrm{~h}$, membranes were dried for $15 \mathrm{~min}$ at $37^{\circ} \mathrm{C}$ and fixed for $1.5 \mathrm{~min}$ under UV. Both membranes were prehybridized together in $25 \mathrm{~mL}$ hybridization solution containing $50 \%$ formamide, $5 \times \mathrm{SSC}$,

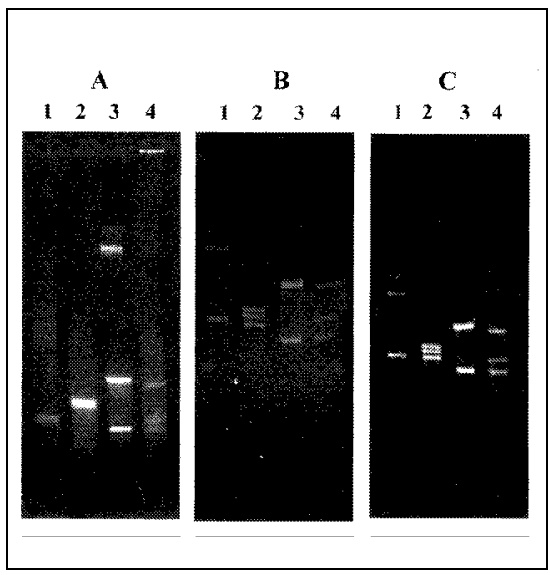

Figure 1. rRNA band patterns obtained after non-denaturing (A), formaldehyde (B) and hot (C) electrophoresis. Lanes 1-3: RNA samples from rat (Rattus norvegicus), fruit fly (Drosophila melanogaster) and bacteria (Escherichia coli), respectively. Lane 4: RNA molecular weight marker (Roche Molecular Biochemicals; from top to bottom: 7.4, 5.3, 2.8, 1.9 and $1.6 \mathrm{~kb}$. The total electrophoresis run was 45 min for (A) and (C), and $2 \mathrm{~h}$ for (B). 
$0.02 \%$ SDS and 2\% blocking reagent (Roche Molecular Biochemicals) during $4 \mathrm{~h}$ at $40^{\circ} \mathrm{C}$. The solution was then replaced with $10 \mathrm{~mL}$ of fresh hybridization solution containing $100 \mathrm{ng} / \mathrm{mL}$ of denatured probe, and hybridization was left overnight at $40^{\circ} \mathrm{C}$. The membranes were washed twice with $5 \times \mathrm{SSC}, 0.1 \%$ SDS at room temperature for $30 \mathrm{~min}$ and then twice with $0.05 \times \mathrm{SSC}, 0.1 \%$ SDS at $62^{\circ} \mathrm{C}$ for $20 \mathrm{~min}$. Colorimetric detection was made using the DIG DNA labeling and detection kit (Roche Molecular Biochemicals) according to the manufacturer's instructions.

Figure 1 shows that the results of rRNA fractionation through the use of formaldehyde (Figure 1B) and hot (Figure 1C) electrophoresis were comparable in regard to the relative electrophoretic mobility of rRNA bands; both were different from the separation in non-denaturing agarose gel (Figure 1A). In the latter case, fruit fly rRNAs conserved a highly structured conformation: $28 \mathrm{~S} \alpha$ and $28 \mathrm{~S} \beta$ rRNA remain associated and therefore appear as a single band, and the 18S rRNA (1995 nucleotides) clearly migrated more slowly than the $1.9 \mathrm{~kb}$ band of the size marker. After electrophoretic separation, the sizes of all visible rRNAs species were estimated from the distances migrated and then compared (Table 1) with the exact values obtained from its known nucleotide sequences

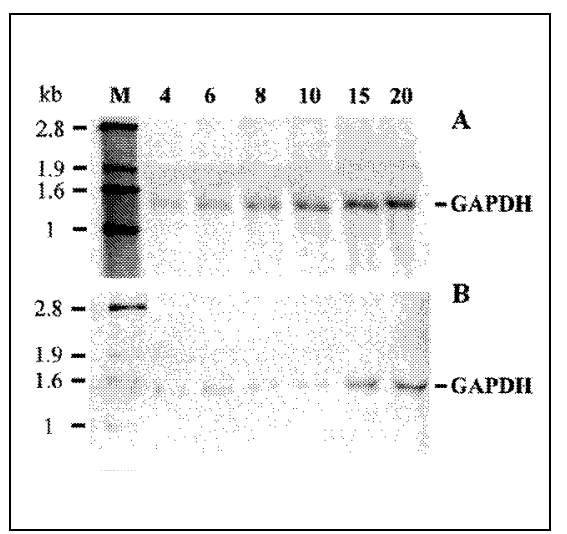

Figure 2. Comparison of blots obtained after transfer from hot agarose (A) and formaldehyde (B) gels. Numbers above the lanes refer to the $\mu \mathrm{g}$ of total RNA loaded. The right lines indicate the $1.4 \mathrm{~kb}$ glyceraldehyde 3-phosphate dehydrogenase mRNA. The molecular weight of the RNA size markers DIG-labeled (M) are indicated on the left. Colorimetric reaction was incubated for $4 \mathrm{~h}$ in (A) and $20 \mathrm{~h}$ in (B).
(GenBank ${ }^{\circledR}$ database). The results confirm that the hot electrophoresis system is suitable for size-fractionation of RNA and allows RNA length calculations with an accuracy level comparable to separations on formaldehyde gels.

Figure 2 shows the Northern blots obtained using nonradioactive hybridization and detection. Both membranes showed comparable relative electrophoretic mobility for the glyceraldehyde phosphate dehydrogenase rat RNA, which, according to its size (1.4 $\mathrm{kb}$ ), migrates faster than the $1.6 \mathrm{~kb}$ RNA marker band. The blot obtained by the hot agarose gel and standard transfer conditions results in an additional increase in sensitivity compared with the formaldehyde one. In fact, in the first case, the colorimetric reaction was stopped after $4 \mathrm{~h}$, while in the second the membrane was incubated for $20 \mathrm{~h}$.

The hot electrophoresis system described here offers many advantages over the traditional denaturing RNA electrophoresis, mainly: (i) absence of toxic compounds in the electrophoresis buffer, (ii) faster separation, (iii) less brittle gels that favor further manipulations as required for staining and Northern blotting and (iv) cleaner visualization of results after ethidium bromide staining as there is no need for extensive washing steps. We also demonstrate that the RNA, after the hot electrophoresis, is suitable for transfer and hybridization, much like the other optimized protocols for this purpose. Finally, the transfer with $10 \times \mathrm{SSC}$ allows the use of a broader range of membranes.

\section{REFERENCES}

1.Bailey, J.M. and N. Davison. 1976. Methylmercury as a reversible denaturing agent for agarose gel electrophoresis. Anal. Biochem. 70:75-85.

2.Ingelbrecht, I.L., C.I. Mandelbaum and T.E. Mirkov. 1998. Highly sensitive northern hybridization using a rapid protocol for downward alkaline blotting of RNA. BioTechniques 25:420-425.

3.Lehrach, H., J. Diamond, J.M. Wozney and H. Boedtker. 1977. RNA molecular weight determinations by gel electrophoresis under denaturing conditions, a critical reexamination. Biochemistry 16:4743-4751.

4.Mc Master, G.K. and G.G. Carmichael. 1977. Analysis of single-and double-stranded nucleic acids on polyacrylamide and agarose gels by using glyoxal and acridine orange Proc. Natl. Acad. Sci. USA 74:4835-4838.

5.Sambrook, J., E.F. Fritsch and T. Maniatis. 1989. Molecular Cloning: A Laboratory Manual. CSH Laboratory Press, Cold Spring Harbor, NY.

Address correspondence to Dr. Teresa A. Almeida. Departamento de Genética, Facultad de Biología, Universidad de La Laguna. C/Astrofísico Francisco Sánchez s/n, E38271, La Laguna, Tenerife, Spain. Internet:tacosalm@ull.es

Received 28 July 1999; accepted 29 November 1999.

Teresa A. Almeida, José A. Pérez and Francisco M. Pinto Universidad de La Laguna Tenerife, Spain 